\author{
Agnieszka Miłosz \\ Faculty of Economics, University of Gdansk, Poland \\ https://orcid.org/0000-0002-7510-8038
}

\title{
SELECTED ASPECTS OF THE FUNCTIONING OF PUBLIC TRANSPORT IN POLAND IN THE LIGHT OF LEGAL CONDITIONS
}

\begin{abstract}
The article presents basic assumptions related to the organization and functioning of the public transport market. The specificity of the market results in a higher degree of formalization of operating principles than commercial markets. Services of general interest of public transport result from the obligation to meet the needs of local communities related to shipments. Three basic entities: organizers, operators and carriers are responsible for the organization and functioning of the public transport market. The rights and obligations of these entities are governed by both national and EU law.
\end{abstract}

Keywords: public transport, market of services of general interest, transport organizer, transport operator, carrier

JEL: R400, R 410, R 480, R 500, R 510, L 330

\section{Introduction}

The market for services of general interest is a specific market. The conditions for the functioning of entities on this market are strictly defined by law. The specificity of the market is already in the very nature of the provision of services, their intangible nature and the simultaneous provision and consumption. The market for services of general interest is a market which operates on principles different from those of the free market, so it is not of a commercial nature. The necessity to meet the needs of local communities, which rests on local government units, results in the fact that this market must be normatively ordered. The norms, however, result not only from the assumptions of the state policy, but also the European Union, which also pays special attention to the sphere of public utilities transport. 
The purpose of the article is to characterize and present the basic principles of organization and functioning of the market for services of general interest based on basic legal acts.

\section{Characteristics of the market for services of general interest}

The nature of public utilities and the implementation of related tasks requires entities operating in this sphere to take a specific look at the organization of the company's business. Public utilities are defined in the Act on municipal economy as "ongoing and continuous satisfaction of the collective needs of the population by providing publicly available services" (Act of 20 December 1996 on Municipal Economy, Journal of Laws U from, 2019). The classification of services as widely available is determined by two main criteria, the social and economic criterion, respectively referred to as utility and payment criteria. According to the above theory, public services are public goods, and the possibility of recognizing a good as public is determined by both the source of payment -in economic terms, and access to these goods -in social terms (Owsiak, p. 25). Public goods are such goods, which can be used by all potential users, and access to them is in no way restricted and equal for all citizens (Samuelson, p. 36). The specific nature of public services means that the implementation of these services requires special attention. The state is responsible for satisfying the collective needs of the population. In response to the needs of local communities, the state formulates public tasks that are implemented through individual local government units (Famulska, p. 15). One of the important tasks of the state meeting the needs of local communities is to ensure regular passenger transport. Such transport is carried out by public transport. The basic definitions, principles of both functioning and organization of public transport are specified in the Act of 16 December 2010 on public transport. The Act defines public transport as, in accordance with the assumption of public utilities, widely available and regular passenger transport, which is carried out as part of a line or communication network at regular intervals. Public transport, on the other hand, is defined as collective transport services that are widely available and provide ongoing and uninterrupted satisfaction of the transport needs of local communities (Act on public collective transport, Article 4.104 .14 ).

Collective transport interchangeably referred to as urban transport or public transport, emerges from the branch of broadly understood transport within the horizontal classification, depending on individual territorial units, within which transport services are performed (Wojewódzka-Król, Załoga, p. 364). Pursuant to the Act on Public Road Transport of 16 December 2010, passenger transport carried out as part of public road transport may take place through municipal passenger transport, public transport, metropolitan passenger transport, international passenger transport and inter-Voivodeship passenger transport (Act on public collective transport, Article 4). Public transport services are carried out as part of various modes of transport, in particular as road transport and rail transport. Road transport, using for transport means of road transport such as bus, trolleybus or passenger car. Rail transport is carried out using means of transport in the form of trams, subways or city railways (Wojewódzka-Król, Załoga, p. 365). 
Public transport plays a very important role in the economy, which is also highlighted in the White Paper, which aims to develop a single European transport area. According to the assumptions of the White Paper, creating an effective transport system is a condition for maintaining the well-being of the European Union. This is possible, among others, by increasing passenger mobility, which contributes to improving the quality of life. Effective transport also affects job creation and economic growth (White Paper, p. 4). The important role of public transport is also emphasized by Regulation (EC) No 1370/2007 of the European Parliament and of the Council of 23 October 2007 concerning public services in the field of rail and road passenger transport. The European Parliament and the Council of the European Union emphasize the need for passenger services as part of caring for the general economic interest, pointing out that such services cannot be commercial (Regulation 1370/2007).

\section{Organization of passenger transport in public transport in the light of the Act on public road transport}

The state oversees the fulfillment of the obligation to ensure passenger mobility, making it responsible for the implementation of tasks related to the organization of public transport. Local government units carry out various public utility tasks, including ensuring mobility for local communities by organizing public passenger transport services. Pursuant to the Act on public transport, the competent local government unit or the minister competent for transport is to ensure the functioning of public transport in a given area. Considering the above, the Act gives local government units, as well as transport ministers, the status of organizer of public collective transport (Act on public collective transport, Article 4.1). Therefore, the transport organizer may be a commune, county, Voivodeship or minister competent for transport. These units are involved in organizing public collective transport in subordinate areas, using communication lines or networks in those areas. Communes, counties and Voivodeships may enter into agreements to organize public collective transport, while communes and counties may form inter-commune associations and county associations (Zamkowska, p. 11664). Depending on the area of operation and range of transport, the organizer's duties are taken over by the local government unit competent for the given area, and the competent executive entity is directly responsible for the implementation of tasks. And so the commune organizes transport on lines or networks located in the commune or communes in the event of an agreement between the communes. The commune head, mayor or city president is responsible for carrying out tasks in this case. In the area of communes forming an inter-commune association, the inter-commune association becomes the organizer, and the association's board is responsible for the tasks. In the case of transport within the county, the organizer is the county, while the tasks are carried out by the governor. Similarly, in the case of an association of counties, county-commune associations, metropolitan associations or Voivodeships, the contractor of the association or marshal of the Voivodeship is the contractor. Finally, passenger transport on inter-Voivodeship and international 
lines or networks is organized by the minister competent for transport (Act on public collective transport, Article 7.1).

The organizer of public transport has to:

- plan the development of transport,

- organize public transport,

- manage public transport (Act on public transport, Article 8).

Therefore, the function of the organizer of public transport is not to carry out transport activities, but to fulfill all obligations regarding organizational and management activities. Therefore, the organizer should undertake, above all, the following activities (Rześny-Cieplińska, p. 52):

- in the scope of transport planning - mediation, development of the transport concept as well as preparation and conclusion of contracts,

- involving the organization and coordination of transport, interchange activities during transport,

- enabling the quality control of completed transports as well as securing documentation.

In addition, organizers of public transport should perform a number of specific tasks such as (Wyszomirski, p. 154):

- research on the demand for transport services,

- undertaking activities conducive to the development of public collective transport,

- working out timetables,

- ticket sale,

- determination of the level of financial demand in the form of subsidies for transport services,

- organizing tenders for the provision of transport services,

- concluding contracts with carriers,

- checks on the implementation of contracts concluded,

- making payments for transport services,

- infrastructure maintenance and ongoing traffic supervision and vehicle traffic regulation,

- preparing and sharing information on the operation of transport.

An important task of the organizer of public collective transport is to perform the function of managing public transport. Management actions consist in particular of (Act on public collective transport, art. 43.1):

- negotiating and approving changes to contracts,

- assessment and control of the implementation of transport services,

- cooperation in updating timetables to improve the functioning of public collective transport,

- analysis of the implementation of the satisfaction of transport needs,

- making changes to the current route of communication lines,

- approving and modifying timetables as needed,

- administering the passenger information system.

Depending on the criteria set out in the Act on public transport, organizers of collective transport are required to create a sustainable transport development plan called a transport plan. Such a plan specifies in particular the planned 
communication networks, assessment and forecasts of transport needs, anticipated financing, preferences regarding the choice of means of transport, principles of organization of the market of carriers, the expected standard of transport services and the expected way of organizing the information system for passengers, as well as communication lines with alternative drives (Act on public collective transport, Article 12.1).

The implementation of transport activities in accordance with the Act on public transport rests with operators and carriers. The operator of public collective transport is "a local government budgetary establishment and an entrepreneur authorized to conduct business in the field of passenger transport, which has concluded a contract with the organizer of public collective transport for the provision of services in the field of public transport, on the communication line specified in the contract." (Act on public collective transport, Article 7.1)

On the other hand, the carrier is "an entrepreneur authorized to conduct business in the field of passenger transport on the basis of confirmation of transport declaration, and in rail transport based on the decision to grant open access" (Act on public collective transport, Article 7.1).

The transport activities of both operators and carriers include (Hartenberger-Liszek, p. 39):

- pre-transport operations - getting the means of transport to the place of loading,

- operations during transport - transport of passengers on route sections,

- operations after transport - return of transport to base.

Contracts for the provision of transport services in the field of public transport grant operators the right and obligation to provide public transport services. Such an agreement may be concluded with a local government budgetary establishment or with another authorized entity selected under the Public Procurement Law Act, the Act on concessions for works or services, or by directly concluding a contract for the provision of public collective transport services. The conditions for a direct conclusion of the contract are as follows:

- the average annual value of the subject of the contract is less than EUR 1 million or transport services will be provided in the amount of less than 300,000 kilometers per year,

- the condition for the performance of services by an internal entity, which is a separate unit subject to the control of the competent local authority, i.e. a company formed by a local government unit to perform public tasks,

- delegation of tasks in the tender procedure or award of concessions as a result of occurrence or high probability of disruptions in the performance of transport services, and inability to meet the deadlines set for concluding the contract. (Czarnecki, p. 61),

- if the directly concluded contract for the provision of services concerns a small or medium-sized enterprise (the SME sector is defined in Commission Regulation (EC) 800/2008 of 6 August 2008 - Annex I), which operates no more than 23 means of transport, thresholds for referred to in point 1 may be increased to the average annual value of the subject of the contract, less than EUR 2 million, or the provision of public collective transport services of less than 600,000 kilometers per year. 
The carrier making a notification about the intention to carry out public transport to the organizer of public transport, after receiving confirmation of such notification from the organizer, may perform non-public transport. The carrier, in accordance with the established rules, and after presenting the proposed timetable and connection diagram, may use the infrastructure in the form of stops and communication stations (Act on public collective transport, Article 43.1). All data regarding both carriers and data regarding the issued transport declaration confirmation are collected in the IT system, whose administrator is the minister competent for transport, called the Central Register of Carriers (Act on public collective transport, Articles 39-40). The terms and conditions for the pursuit of the occupation of carrier are also set out in a regulation of the European Parliament and of the Council establishing common rules concerning the conditions for the pursuit of the occupation of road transport operator. The regulation stresses the need to shape the market based on fair competition rules. This approach will enable raising the level of carriers' professional qualifications, rationalizing the market, as well as improving the quality of services rendered and increasing road safety (Regulation 1071/2009).

Passenger transport in the framework of public collective transport should take place in accordance with certain rules. Particular attention is paid to the appropriate adaptation of means of transport to carry passengers so that they meet all technical requirements, as well as to their marking in a way visible to the passenger. Operators and carriers are also required to make public schedules, placing them at all transport stops and stations. Price lists and tariffs for transport charges established on the basis of separate regulations must also be made public. At stations, there should also be publicly available rules of passenger transport in public collective transport, developed by the organizer, operator or carrier (Act on public collective transport, Article 46.1).

Passenger transport is carried out by economically, legally and technically separated entities. Enterprises providing transport services not constituting public utilities, operate on the basis of market law of demand and supply. Enterprises providing public transport services are referred to as public transport companies. These companies provide transport services consisting in the passenger transport, thus satisfying the needs of the population related to transport (Miłosz, p. 195).

The market for services of general interest is governed by slightly different laws, since it does not meet all the features of a free market. The difference is noticed especially in processes related to shaping service prices as well as shaping competitiveness. Enterprises of public utility transport services for effective functioning require financial assistance from the state, and such assistance can be obtained in the form of subsidies (Zagożdżon, p. 219). The Act on public transport sets out detailed rules and methods of financing public transport services, indicating as sources of financing (Act on public collective transport art. 50.1):

- fees charged by the operator or organizer in connection with the performance of transports,

- compensation for lost revenues and incurred costs,

- providing operators with means of transport.

The Act on public transport therefore defines the conditions and rules for the functioning of the public transport collective sphere. The development 
of the market of public utility transport services and many years of economic practice in this matter caused that functional and organizational problems began to be noticed, as a result of which in February 2018 the Draft Act amending the Act on public road transport and some other acts was created. The full entry into force of the Act is to take place on January 1,2022, while the main goal of the Act is to improve the functionality of transport, ensure transport consistency and prevent traffic exclusion for citizens residing in areas far away from urban agglomerations. The main directions of changes in the Act are presented in the table.

Table 1. Directions of changes to the Act on public transport

\begin{tabular}{|c|c|c|c|}
\hline No. & Record in the act & Act in force & Draft changes \\
\hline 1 & $\begin{array}{l}\text { Percentage of the number of journeys on public } \\
\text { transport lines intended for public transport } \\
\text { operators, excluding public transport }\end{array}$ & No record & At least $60 \%$ \\
\hline 2 & $\begin{array}{l}\text { Commune's obligation to provide transport } \\
\text { of children to schools as part of public collective } \\
\text { transport if the means of transport does not stop } \\
\text { in a given place }\end{array}$ & No record & Yes \\
\hline 3 & Obligation to create transport plans & $\begin{array}{l}\text { According } \\
\text { to the demographic } \\
\text { criterion }\end{array}$ & $\begin{array}{l}\text { An absolute } \\
\text { obligation }\end{array}$ \\
\hline 4 & Update of transport plans & If necessary & Every 3 years \\
\hline 5 & $\begin{array}{l}\text { Time of conclusion of the contract for } \\
\text { the provision of public services }\end{array}$ & Max 10 years & Max 8 years \\
\hline 6 & Permission to carry out commercial transport & $\begin{array}{l}\text { No restrictions - } \\
\text { as requested }\end{array}$ & $\begin{array}{l}\text { Only } \\
\text { on communication } \\
\text { lines specified } \\
\text { in the transport } \\
\text { plan - does } \\
\text { not apply } \\
\text { to inter-Voivodeship } \\
\text { transport }\end{array}$ \\
\hline 7 & Period of commercial transport & $\begin{array}{l}\text { Based } \\
\text { on the confirmation } \\
\text { of the application - } \\
\text { max } 5 \text { years } \\
\end{array}$ & $\begin{array}{l}\text { Based } \\
\text { on the permit - max } \\
8 \text { years }\end{array}$ \\
\hline 8 & Central Carrier Register & Yes & No \\
\hline 9 & $\begin{array}{l}\text { The right to receive subsidies also for commercial } \\
\text { carriers }\end{array}$ & No & Yes \\
\hline
\end{tabular}

Source: own study based on: https://bip.kprm.gov.pl/kpr/form/r9477595673663,Projekt-ustawy-o-z changes-ustawy-o-publicznych-transport-zbiorowym-oraz-niektory.html

Therefore, the changes affect all entities functioning as part of public collective transport. Bearing in mind the public interest and the good of society, the obligation to create transport plans diagnosing the current situation and determining accessibility standards and the demand for transport, especially transporting children to schools, was introduced above all. The changes will also apply to commercial carriers, for which the duration of transport permits has been shortened, specifying their market share in the transport plan. 


\section{The terms and conditions for financing public transport services from the Bus Transport Development Fund}

The form of public utilities in which public collective transport is implemented, and the policy related to price formation for these services, make these transport largely unprofitable. A limited amount of cash for financing transport reduces or eliminates transport on certain lines, which results in the exclusion of some areas of transport. The traffic exclusion is to be prevented by the Act of 16 May 2019 on the Fund for the development of public transport bus services. The assumption of the Act is the creation of a special-purpose fund managed by the minister competent for transport. The purpose of the Fund is to accumulate financial resources and allocate them to finance the own tasks of local government units in the field of public bus transport. Thus, the fund is dedicated to organizers of public collective transport, and the funds from the fund will contribute to an increase in the number of transport offered, which should reduce or eliminate transport exclusion. The provisions of the Act do not apply to transport carried out as part of public transport (https://www.gov.pl).

Fund resources, which are mainly allocated for co-financing in the form of a surcharge to the price of the service, come from:

- revenues from the issue fee $-5 \%$ of revenues,

- revenues from substitution fees $-55 \%$ of revenues,

- proceeds from the fuel surcharge $-4 \%$ of revenues,

- state budget,

- interest on surcharges returned,

- interest on the Fund's interest rate,

- donations and bequests,

- revenues resulting from other acts.

A condition for receiving a grant, which may range from PLN 0.80 to PLN 1 to the vehicle-kilometer (the vehicle-kilometer means the unit of measure for the operational operation of the bus, with 1 vehicle-kilometer for the passage of 1 bus over a distance of 1 kilometer) of public utility transport is the conclusion of a contract statement of public transport services (Act on the development fund..., Article 12), and the organizer's own contribution to the financing of these services in the amount of at least $10 \%$ of the price of the service (Act on the development fund ..., Article 14.7). Another condition is the negative net financial result obtained in the accounting period for a single communication line, not including a reasonable profit (Act on the development fund..., Article 14.3). A reasonable profit should be understood as the rate of return on capital which in a given Member State is considered normal for this sector and in which the risk or lack of risk of interference by a public body incurred by the public service provider has been taken into account (Regulation 1370/2007 - annex). Receipt of financing is also possible only after the organizer has submitted a formal application for additional payment, as well as when the Fund's account has available funds. Subsidies from the Fund are subject to the following communication lines (Act on the development fund..., Article 22):

- inoperative for at least 3 months before the date of entry into force of the Act, 
- on which the contract for the provision of public collective transport services will be concluded after the date of entry into force of the Act.

The administrator of the fund draws up an annual financial plan specifying the amount of revenues and expenses under the Fund. Then, the administrator's task is to divide the funds in accordance with the assumptions of the financial plan among the Voivodeships, taking into account (Act on the development fund..., Article 24):

- area of the Voivodeship,

- number of residents,

- operational work on communication lines in public transport of public transport, expressed in vehicle-kilometres, planned to be carried out according to transport plans.

Thus, procedures related to co-financing under the Fund are commenced by the Council of Ministers specifying in the regulation a detailed breakdown of resources, taking into account the above conditions. In the next step, the minister competent for transport divides the funds provided for a given financial year in the financial plan of the Fund, and then informs the voivode about the amount of funds allocated for payments under the fund in a given Voivodeship. However, the voivode is obliged to provide information on the maximum amount of additional payment to one vehicle per kilometer in the Public Information Bulletin. In addition, the governor publishes information on the deadlines for submitting applications for subsidies by transport organizers.

One of the conditions for receiving a subsidy from the Fund is the conducting the contract, and it is preceded by the following steps:

- planning public transport in a specific area,

- announcement of the intention to award a public contract,

- conducting the contract award procedure and selecting the operator.

The obligation to develop a transport plan lies with the organizers whose intention is to organize public transport, and to those who meet the criterion related to the number of residents, in accordance with the Public Transport Act.

Table 2. Conditions for developing the transport plan

\begin{tabular}{|l|c|c|}
\hline \multicolumn{1}{|c|}{$\begin{array}{c}\text { Criterion } \\
\text { Organizer }\end{array}$} & $\begin{array}{c}\text { The intention to organize public } \\
\text { transport }\end{array}$ & The number of residents \\
\hline Commune & Yes & 50000 \\
\hline $\begin{array}{l}\text { Association of municipalities } \\
\text { Inter-municipal association } \\
\text { County-commune association }\end{array}$ & Yes & 80000 \\
\hline $\begin{array}{l}\text { Union of counties } \\
\text { County agreement }\end{array}$ & Yes & 120000 \\
\hline Voivodeship & Yes & No limit \\
\hline
\end{tabular}

Source: Own study based on the Act on Public Transport 
The development of a transport plan requires a diagnosis of the current situation on a given market of public utilities. After a preliminary analysis of satisfying the transport needs of local communities, it is possible to assess the legitimacy of organizing public transport services in a given area.

Before applying for a subsidy from the fund, the organizer must publish an announcement about the intention to conduct a tender procedure or to conclude a contract directly:

- not less than a year ago, or

- 6 months - when the contract is to involve the provision of services less than 50,000 kilometres a year.

The publication of an announcement may take place by means of an advertisement in:

- the Official Journal of the European Union,

- Public Information Bulletin,

- in a publicly accessible place at the organizer's headquarters,

- on the organizer's website if it has one.

The operator is selected in the mode specified in the Act on public collective transport.

Finally, operators in the current situation can finance public transport activities in the form of:

- subsidy for tickets,

- subsidies from the Bus transport development fund,

- specific subsidies as a source of co-financing for local government units.

The amounts granted for individual Voivodeships and used in the form of subsidies granted this year are presented in the table below.

Table 3. Amounts allocated for subsidies from the Bus Development Fund and their use

\begin{tabular}{|c|c|c|c|c|}
\hline No. & Voivodeship & $\begin{array}{l}\text { Amount } \\
\text { awarded }\end{array}$ & Amount used & $\begin{array}{c}\text { Number of lines } \\
\text { running }\end{array}$ \\
\hline 1 & Lower Silesia & 20194015,24 & No data & No data \\
\hline 2 & Kuyavian-Pomeranian & 18498597,84 & 167000,00 & 41 \\
\hline 3 & Lublin & 24246395,01 & No data & No data \\
\hline 4 & Lubusz & 13173440,89 & 236560,00 & 36 \\
\hline 5 & Łódź & 15586487,12 & 2500000,00 & 92 \\
\hline 6 & Lesser Poland & 16158111,16 & No data & No data \\
\hline 7 & Masovian & 19705448,76 & 2747207,00 & 240 \\
\hline 8 & Opole & 11638440,47 & No data & No data \\
\hline 9 & Podkarpackie & 19640405,80 & 3293278,00 & 207 \\
\hline 10 & Podlasie & 24818469,49 & 830000,00 & 70 \\
\hline 11 & Pomeranian & 15813935,77 & 1536043,00 & 83 \\
\hline 12 & Silesia & 18386185,25 & No data & No data \\
\hline 13 & Świętokrzyskie & 21484820,55 & 263492,00 & 44 \\
\hline 14 & Warmian-Masurian & 22912917,13 & 294567,00 & 35 \\
\hline 15 & Greater Poland & 19823272,26 & 700000,00 & 100 \\
\hline 16 & West Pomeranian & 17919057,25 & 256853,00 & 26 \\
\hline
\end{tabular}

Source: Own study based on: https:/www.gov.pl/web/gov/uw 
The table shows to what extent the funds from the Fund were used. In most Voivodeships, just over $1 \%$ of the funds were used. The best results are shown by the Łódź and Masovian Voivodeships, where the funds used are within 15\% of the amount allocated. This is certainly due to time constraints and a large number of necessary procedures and formalities. The act entered into force on May 16, 2019 and local governments could submit applications from August 1 to August 12 this year. Considering the formal requirements before submitting the application and the lack of provisions in the Act regarding the elements that should include the application, the procedure was difficult.

\section{Conclusions}

As it can be noticed, the market for services of general interest is a fairly regulated market. Both the state and the European Union in individual documents propose solutions aimed at improving the functionality, quality and comfort of passenger transport. Practice in the field of passenger transport, passenger requirements, financial capabilities of local governments, especially in the public utilities market, show that this market requires changes and correction of existing conditions. An essential element of the state's transport policy is to be guided by the desire to ensure sustainable transport development by increasing passenger mobility and gradually eliminating individual transport. Both organizers: operators and carriers must be guided by generally accepted criteria and organize their own tasks within the prescribed legal and time frame. One of the biggest problems of public transport is the issue of financing. These transportations are to a large extent not very profitable or become unprofitable, which means that lines in unprofitable areas are eliminated, which results in so-called white transport spots. In addition to price subsidies and targeted subsidies the rescue at least for some appears to be the newly created Public Transport Development Fund. Time will show to what extent previously unprofitable lines have been restored and to what extent this will reduce the occurrence of white transport spots.

\section{References}

Czarnecki K, 2013 Rola gminy w systemie organizacji i finansowania publicznego transportu zbiorowego, Prawo Budżetowe Państwa i Samorządu 1(1)/2013

Famulska T, 2009, Gospodarka finansowa Jednostek Samorządu Terytorialnego, praca zbiorowa, Wyd. Uniwersytetu Ekonomicznego, Katowice

Hartenberger - Liszek J, 2013, Kondycja finansowa przewoźników w świetle procesów integracji publicznego transportu zbiorowego Trójmiasta, w: Zeszyty naukowe Uniwersytetu Gdańskiego. Ekonomika transportu i Logistyka Nr 53, praca zbiorowa pod red: K. Szałuckiego i A. Letkiewicza, Wydawnictwo Uniwersytetu Gdańskiego, Gdańsk

K. Wojewódzka - Król, E. Załoga, 2016Transport, nowe wyzwania, praca zbiorowa, PWN Warszawa,

Miłosz A, 2016, Problemy poznawcze analizy strategicznej przedsiębiorstw użyteczności publicznej transportu w: Zeszyty naukowe Uniwersytetu Gdańskiego Ekonomika transportu i logistyka nr 59. Wyzwania rozwoju transportu, praca zbiorowa pod red. A. Letkiewicza, Wyd. Uniwersytetu Gdańskiego, Gdańsk 
Owsiak S, 2004, Finanse publiczne. Teoria i praktyka, PWN, Warszawa 2004,

Rześny - Cieplińska J, 2013, Organizatorzy transportu w kształtowaniu ładu przestrzennego gospodarki, Wydawnictwo Uniwersytetu Gdańskiego, Gdańsk

Samuelson A, Nordhaus W. D., 2014, Ekonomia, Dom Wydawniczy REBIS, Poznań

Wyszomirski O, 2002, Gospodarowanie w komunikacji miejskiej, praca zbiorowa, Wydawnictwo Uniwersytetu Gdańskiego, Gdańsk

Zagożdżon B, 2003, Komunikacja miejska jako element sektora publicznego, w: Liberalizacja transportu w warunkach transformacji gospodarczej, praca zbiorowa pod red. G. Dydkowski, R. Tomanek, Wydawnictwo Akademii Ekonomicznej, Katowice

Zamkowska S, 2014 Rola i zadania organizatora przewozów w świetle ustawy o publicznym transporcie zbiorowym, Logistyka 6/2014

Komisja Europejska, 2011, Biata Księga Transportu -Plan utworzenia jednolitego europejskiego obszaru transportu - dążenie do osiagnięcia konkurencyjnego i zasobooszczędnego systemu transportu, Urząd Publikacji Unii Europejskiej, Luksemburg

Ustawa z dnia 16 grudnia 2010r o publicznym transporcie zbiorowym

Ustawa z dnia 20 grudnia 1996r o Gospodarce Komunalnej, Dz. U z 2019

Ustawa z dnia 16 maja 2019r o Funduszu rozwoju przewozów autobusowych o charakterze użyteczności publicznej

Rozporządzenie (WE) nr 1370/2007 Parlamentu Europejskiego i Rady z dnia 23 października $2007 \mathrm{r}$

Rozporządzenie Parlamentu Europejskiego i Rady (WE) Nr 1071/2009 z dnia 21 października 2009 r. ustanawiające wspólne zasady dotyczące warunków wykonywania zawodu przewoźnika drogowego i uchylające dyrektywę Rady 96/26/WE

Załącznik do rozporządzenia (WE) nr 1370/2007 z dnia 23 października 2007roku, dotyczącego usług publicznych w zakresie kolejowego i drogowego przewozu pasażerskiego

https://bip.kprm.gov.pl/kpr/form/r9477595673663,Projekt-ustawy-o-zmianie-ustawy-o-pu blicznym-transporcie-zbiorowym-oraz-niektory.html

https://www.gov.pl/web/gov/uw

\section{Corresponding author}

Agnieszka Miłosz can be contacted at: agnieszka.milosz@ug.edu.pl 